\title{
REQUALIFICAÇÃO URBANA E DESPEJOS EM CENTROS NOVO E ANTIGO DE SALVADOR ${ }^{1}$
}

A Ivana Chastinet, in memoriam²

\author{
John Gledhill* \\ Maria Gabriela Hita * *
}

\begin{abstract}
A cidade de Salvador replica o processo de "acumulação por espoliação", característico de um urbanismo neoliberal em todo o mundo. Neste artigo, comparamos como atua a lógica da requalificação urbana em duas zonas da cidade. A primeira é uma grande e historicamente combativa favela localizada na região que tem se tornado o mais moderno "novo centro" da cidade. Nela, a chave dos problemas são os novos projetos de mobilidade urbana e a construção de condomínios para outras classes sociais. A segunda zona é o centro colonial da cidade, que experimenta uma nova fase de gentrificação. Ali, as políticas de patrimônio histórico se encontram com outras políticas, transformando os remanescentes espaços públicos da cidade neoliberal securitizada em zonas mais seguras para turistas e residentes mais ricos. Enfatizamos o valor de um entendimento etnograficamente fundamentado para compreender o que essas mudanças significam para moradores pobres da cidade, assim como a complexidade, a heterogeneidade e a ambiguidade de suas diferentes reações.

Palavras-Chave: Cidades. Pelourinho. Gentrificação. Despejos. Resistências.
\end{abstract}

\section{CONTEXTO LOCAL, TENDÊNCIAS GLOBAIS}

Atualmente, a cidade de Salvador está passando por um processo de requalificação e de desenvolvimento dos espaços públicos, bem conhecido por muitos turistas que visitam a primeira capital colonial do Brasil, provenientes do país e do resto do mundo. Essa renovação seguiu-se a um período em que as classes média e alta soteropolitanas protestavam em função da decadência geral da cidade

\footnotetext{
* Universidade de Manchester. Departamento de Antropologia Social.

Oxford Road. Manchester M13 9PL. Reino Unido

john.gledhill@manchester.ac.uk

** Universidade Federal da Bahia. Departamento de Sociologia. dos Programas de Pós-Graduação em Ciências Sociais (PPGCS) e o de Estudos Interdisciplinares sobre Mulheres, Gênero e Feminismo (PPGNEIM).

R. Prof. Aristides Novis, 197. Cep: 40210-909. Federação Salvador - Bahia - Brasil.mghita63@gmail.com

${ }^{1}$ Artigo traduzido do inglês por Phillip Villani, originalmente apresentado na sessão "Exploring and questioning the inner-city in Latin America: urban renewal, historic preservation, gentrification and segregation dynamics" no congresso de cinquenta anos da Associação de Estudos Latino-Americanos, Nova Iorque, 29 de maio, 2016. Dra. Hita agradece ao CNPq pelo apoio financeiro recebido para participar dessa LASA. Versão sintética foi também apresentada no Congresso da UFBA 70 anos, em 2016, na Mesa Redonda
}

após a gestão de dois mandatos de João Henrique Carneiro (2005-2012) como prefeito. Seu sucessor, eleito em 2012 e reeleito em 2016, é neto do famoso cacique baiano, o ex-governador e senador Antônio Carlos Magalhães, popularmente conhecido como ACM. O contentamento de Antônio Carlos Peixoto de Magalhães Neto de ser publicamente conhecido simplesmente como ACM Neto reflete o fato de que seu avô ainda ocupa um lugar nos corações de muitos baianos. Os apoiadores do velho ACM, no entanto, não incluíram membros de muitas das famílias, em sua maioria negras, despejadas de suas casas durante sua iniciativa de modernizar uma metrópole do século vinte em rápida expansão, através de uma atualizada rede de transportes que vem sendo implantada desde as décadas de 70 e 80. Esse

"Disputas Urbanas em Grandes Metrópoles: um balanço da situação na Argentina e Brasil” coordenada pela Dra. Hita. Dados etnográficos sobre o Bairro da Paz, aqui atualizados, têm sido já apresentados em outras publicações.

${ }^{2}$ Ivana Chastinet, artista, performer, diretora teatral e cenógrafa, a quem dedicamos este artigo, é especialmente reconhecida como lutadora e ativista em defesa do Centro Histórico de Salvador. Criadora do Movimento Bairro 2 de Julho e moradora resistente do assentamento Coração Vila de Maria, no Bairro 2 de Julho, morreu no dia 8 de Agosto de 2017, deixando um grande vazio nesse movimento e no coração dos seus incontáveis amigos e conhecidos. 
processo de requalificação urbana, iniciada por antecessores, culminou com a reforma do coração do Centro Histórico decadente, o Pelourinho, declarado patrimônio mundial pela UNESCO em 1985.

A derrota do candidato de ACM para prefeito em 2004, com a vitória de João Henrique, refletiu o poder cada vez menor dessa máquina política, e o crescimento do Partido dos Trabalhadores (PT) na Bahia, nos anos vindouros. Jacques Wagner ganhou o governo estadual para o PT em 2007, retendo-o por dois mandatos. Apesar da retomada do município por ACM Neto e os Democratas (DEM) em 2012, nas eleições de 2014, um novo governador do PT, Rui Costa, nascido e criado em um bairro de classe trabalhadora da cidade, foi eleito por uma maioria confortável no primeiro turno. Assim, o PT, mediante o voto popular, retomou o controle político local, derrotando a rede de controle do Carlismo, estabelecida por meio do clientelismo. Com sua força eleitoral em 2014, tanto no interior da Bahia quanto dentre os moradores urbanos pobres e a classe trabalhadora, a vitória do PT refletiu o peso da geração de novos empregos, muitos deles com carteira assinada, dos salários crescentes e da sensação, nesses anos, de maior avanço pessoal, pelo acesso maior a bens consumíveis, com a maior disponibilidade de crédito fácil. Esse quadro também $\infty$ é resultante dos efeitos positivos do programa จ . Bolsa Família, do PT. Os governos estaduais desse Partido poderiam se vangloriar ainda dos สี่ ganhos conquistados em projetos populares de i moradia e das melhorias no acesso a serviços 今े médicos, alcançadas pelos menos favorecidos. i. Também poderia ser creditada a esses governos

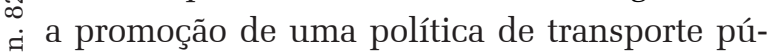
के blico mais racional para a cidade de Salvador,

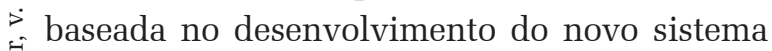
de metrô e de trens leves sobre trilhos (VLT).

No entanto, o caso de Salvador mostra que o PT também foi cúmplice na promoção de um modelo de desenvolvimento urbano neoliberal. Embora, quanto a esse aspecto, tenha se espelhado em outros governos demo- cráticos sociais do mundo inteiro em termos daquilo que ofereceu aos moradores pobres das áreas metropolitanas, o financiamento das campanhas eleitorais do PT por empresas imobiliárias e construtoras claramente lhe gerou certos compromissos. ${ }^{3}$

Poderia, entretanto, parecer irônico que o Brasil seja exemplo de um modelo de desenvolvimento urbano neoliberal, dado o teor progressista de sua Constituição de 1988 e o fato de o direito à moradia ter sido levado consideravelmente mais longe pelo Estatuto da Cidade de 2001 (Lei Federal 10.257). Nessa Lei, foram reconhecidas as funções sociais da propriedade e foi posta a determinação de que os planos de desenvolvimento urbano deveriam considerar a participação popular ampla e socialmente inclusiva. Ela reflete o espírito promovido pela Conferência das Nações Unidas Habitat-I e um padrão internacional adotado por legislações urbanas socialmente mais progressistas em todo o mundo. Porém, como urbanistas brasileiros enfatizaram (Maricato, 2013; Rolnik; Klink, 2011), há uma grande diferença entre o que esse Estatuto promete teoricamente e o que o governo (em todos os seus níveis) tem feito, na prática. A base dessa crítica foi ampliada quando ocorreram novas experiências de despejos associados às preparações do país para a Copa do Mundo e os Jogos Olímpicos (Faulhaber; Azevedo, 2015; Serpa, 2017). Mesmo quando "consultas" baseadas em "participação popular" foram promovidas - raras no caso baiano -, esses exercícios frequentemente têm mostrado susceptibilidade à manipulação para legitimar decisões de planejamento urbano já tomadas. O que acontece, na prática, tende a refletir uma lógica política de democracias eleitorais, em países de capitalismo neoliberal,

${ }^{3}$ Embora a construtora Camargo Correa também tenha sido um agente importante na reforma urbana de Salvador, a Odebrecht, fundada em 1944, e a OAS, fundada em 1976, são especialmente importantes, como empresas baianas que atingiram um alcance internacional. Elas deram mais financiamento para o PT do que para seus competidores, em lugares onde petistas eram os vencedores eventuais mais prováveis. Outras empresas imobiliárias também investiram em ONGs e projetos comunitários em bairros pobres, adjacentes a seus empreendimentos, em parte por motivos vinculados a relações públicas, mas também para facilitar a comunicação com lideranças comunitárias, e, em alguns casos, sua cooptação (Gledhill; Hita, 2014). 
nas quais os principais perdedores, no padrão de desenvolvimento urbano vigente, não costumam possuir força suficiente para que seus interesses sejam contemplados.

O poder político relacionado a interesses de grandes empreendedoras imobiliárias e de grandes construtoras é uma consequência do modo como a desindustrialização e a substituição de empregos fabris pelos empregos no setor de serviços fizeram do desenvolvimento urbano uma base importante da acumulação do capital nas últimas décadas do século vinte. O financiamento do processo de acumulação também estimulou a especulação imobiliária, com o risco concomitante de estourar a bolha imobiliária, através do processo de construção de novas casas para as quais nenhum comprador seria encontrado (Serpa, 2017). Tudo isso é particularmente preocupante no caso das cidades brasileiras, há muito tempo divididas entre o "setor formal" das áreas residenciais, ocupadas pelas famílias das classes média e alta, e o setor muito maior, em que a informalidade ainda domina a ocupação da terra e a construção. E isso ocorreu apesar de o governo petista ter se esforçado em tentar ajudar cidadãos com uma renda mais baixa a entrar no mercado imobiliário formal (Maricato, 2003).

Ao longo dos anos da administração de João Henrique Carneiro - durante a qual os motoristas de Salvador não precisavam atentar para as câmeras fotográficas de controle de velocidade, mas, sim, deviam se concentrar para evitar os buracos nas ruas, uma vez que a Prefeitura não pagava as dívidas das empresas privadas contratadas para manutenção das referidas câmaras -, a cidade presenciou um boom de construção espetacular, até para os padrões típicos encontrados nas metrópoles brasileiras. Apesar de sua aclamada ineficiência, a administração de Carneiro mostrou ser uma colaboradora efetiva do setor privado que atuava nesse processo de desenvolvimento urbano. Ela flexibilizou a aplicação da regulamentação de construção e de controle ambiental, modificando a Lei de Ordenamento do Uso e da Ocupação do
Solo (LOUOS) a tal ponto, que ficou mais fácil para capitalistas imobiliários explorarem localizações mais privilegiadas, antes protegidas por essas leis. Em teoria, leis municipais obrigavam as construtoras a compensarem o município por financiar projetos de moradia popular, quando elas obtinham concessões especiais, a fim de evitar restrições, como nas edificações de elevada altura em zonas próximas às praias da cidade. Novamente, aqui, políticos da cidade mostraram ser bem mais "flexíveis" na prática de emitir essas licenças.

Muitos questionamentos foram levantados sobre a validade dos títulos de terra obtidos por essas agências imobiliárias quando construíram em sítios de áreas verdes. A propriedade de terras nas fronteiras da cidade em expansão costuma ser uma questão ambígua e amplamente disputada por diversos dos atores envolvidos. Até a segunda metade do século vinte, a maior parte das terras de Salvador pertencia ao município ou a corporações da Igreja Católica, que pouco se preocupavam com os interesses seculares privados, porque podiam alugar essa terra pública perpetuamente, recebendo alugueis anuais fixos.

Um dos primeiros atos de ACM (avô), após ser nomeado pelos militares como prefeito de Salvador em 1967, foi a reedição da "Lei de Reforma Urbana”, que obrigava residentes a comprarem a terra alugada, com dinheiro ou por devolução de parte de seu arrendamento não pago à cidade em terras, e aquelas que o município queria manter (por atraso de aluguel ou por impostos não pagos). Dantas Neto (2006) argumenta, como o fazem também muitos urbanistas, que o principal beneficiário dessas medidas legislativas de ACM foi o capital imobiliário. E que os principais perdedores foram as famílias afro-brasileiras pobres, que não possuíam um título legal das terras, agora municipais, pois tinham se estabelecido em terrenos que já eram objeto de interesses imobiliários para requalificação, em atendimento a demandas de moradores de classes sociais mais altas e a requisições do turismo. 
O boom imobiliário do século XXI, em Salvador, é visível tanto em áreas residenciais de luxo, bem estabelecidas, como em prédios de apartamentos modestos, construídos para beneficiários do programa Minha casa, minha vida. Porém sua manifestação mais visível se encontra nos pontos de entrada Norte da cidade (vide Mapas 1 e 2). Ali, novos shoppings e condomínios residenciais são nitidamente associados a espaços que buscam oferecer aos soteropolitanos mais abastados uma "vivenda segura”, com toques de verde, apesar da crescente destruição extensiva da Mata Atlântica que o desenvolvimento dessa região provocou. Localizada entre o aeroporto internacional e o Centro Administrativo da Bahia (CAB) - que ACM inaugurou em 1972, durante seu primeiro mandato de Governador -, essa zona norte já se tornou outro novo "centro", o mais moderno de uma cidade cada vez mais "poli(multi)nucleada” (Santos, 2013).

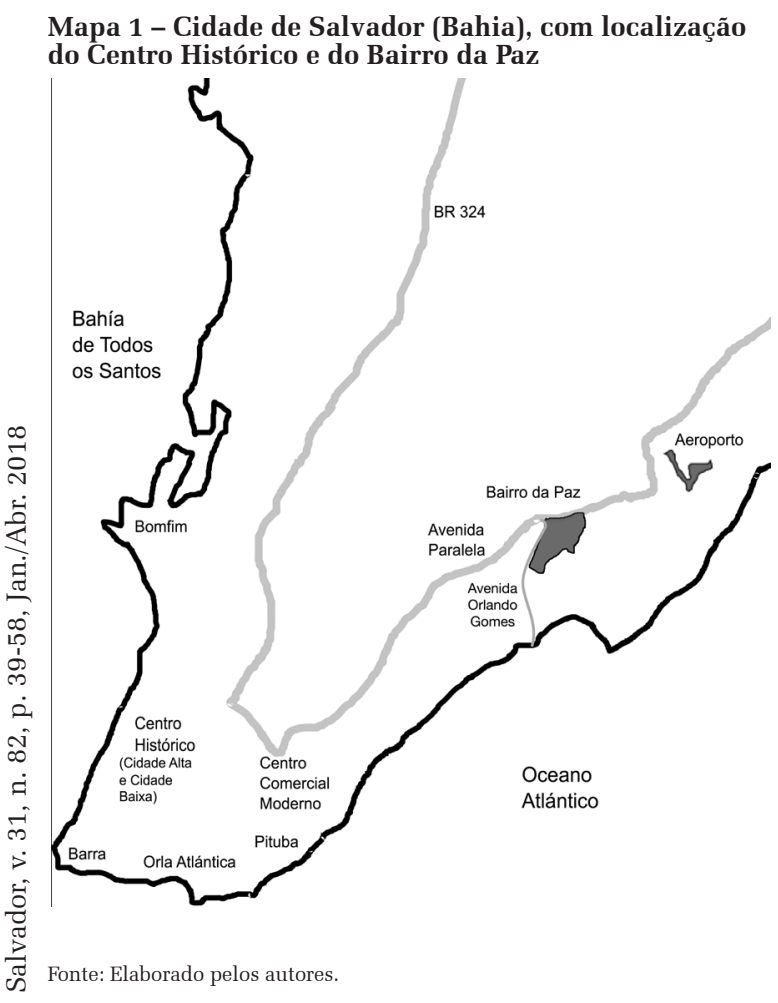

Esse segundo centro residencial e comercial evoluiu muito mais depois da construção do Centro Administrativo da Bahia
(CAB) na região do Iguatemi (ou zona de Camaragibe, como é identificada por Vasconcelos, 2016), nas proximidades de onde fora instalado o novo terminal da rodoviária interestadual da cidade e o primeiro shopping da Bahia, inaugurado em 1975. O desenvolvimento do Shopping Iguatemi (hoje rebatizado como Shopping da Bahia) e o crescimento dos bairros

\section{Mapa 2 - Bairros da cidade de Salvador (Bahia)}

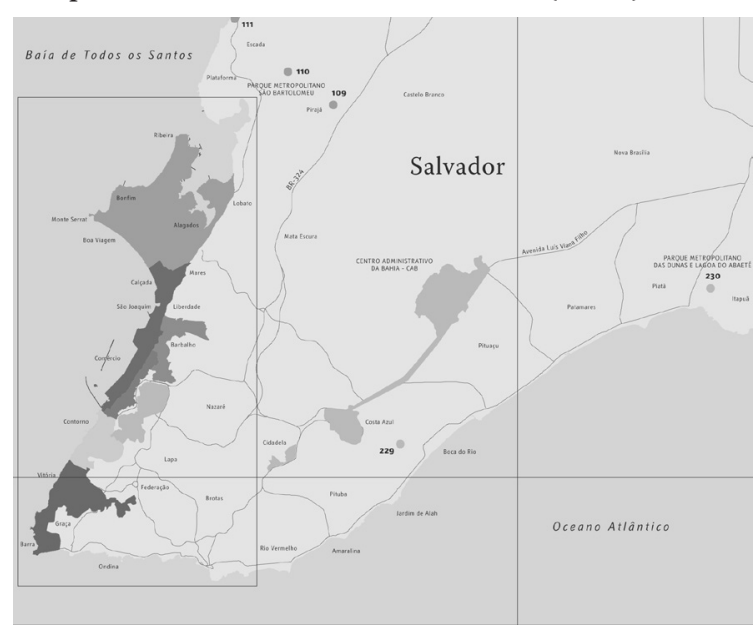

Fonte: (Plano... [20--]).

vizinhos, de classe média alta, como Pituba, Itaigara, Candeal e Imbuí, são indicadores dessa onda de deslocamento das classes alta e média das zonas do centro antigo, habitadas no passado, para irem cada vez mais para a orla atlântica norte, longe da Cidade Alta e da Cidade Baixa originais, estabelecidas pelos portugueses ao estilo de Lisboa, na Salvador da era colonial. Contudo as elites da cidade já tinham abandonado os velhos casarões do antigo centro histórico bem antes disso, durante o século dezenove, quando se deslocaram para bairros então mais próximos aos de suas anteriores moradias, como os da Graça e do Corredor da Vitória, época em que Salvador, como metrópole, já tinha sido ultrapassada pelo Rio de Janeiro (Santos, 1959; Vasconcelos, 2016).

Abandonado pelas elites, o Pelourinho, situado no Centro Histórico da Cidade Alta 
de Salvador, foi deixado para moradores da classe trabalhadora (vide Mapa 3). Enquanto as mansões antigas desabavam, seus novos moradores criaram suas casas dentro dessas ruínas, incluindo mulheres que descobriram uma vida de prostituição mais vantajosa do que se dedicarem ao serviço doméstico. Apesar de ter sido objeto do discurso estigmatizante dos fundadores da cidade, que publicamente lamentaram decadência moral e a "ruína" dessa joia do patrimônio da cultura colonial, o antropólogo John Collins mostrou que a área de prostíbulos, com bares e bordeis, que surgiu no coração do Pelourinho, teve papel central na vida social e até política dos governantes e dos "bons homens de famílias" de Salvador, assim como de intelectuais e "boêmios" da cidade (Collins, 2015). Mas, no final das contas, havia motivos políticos e econômicos mais fortes para se avançar em direção ao que ACM descrevera como o processo de "devolver o Pelourinho à cidade".

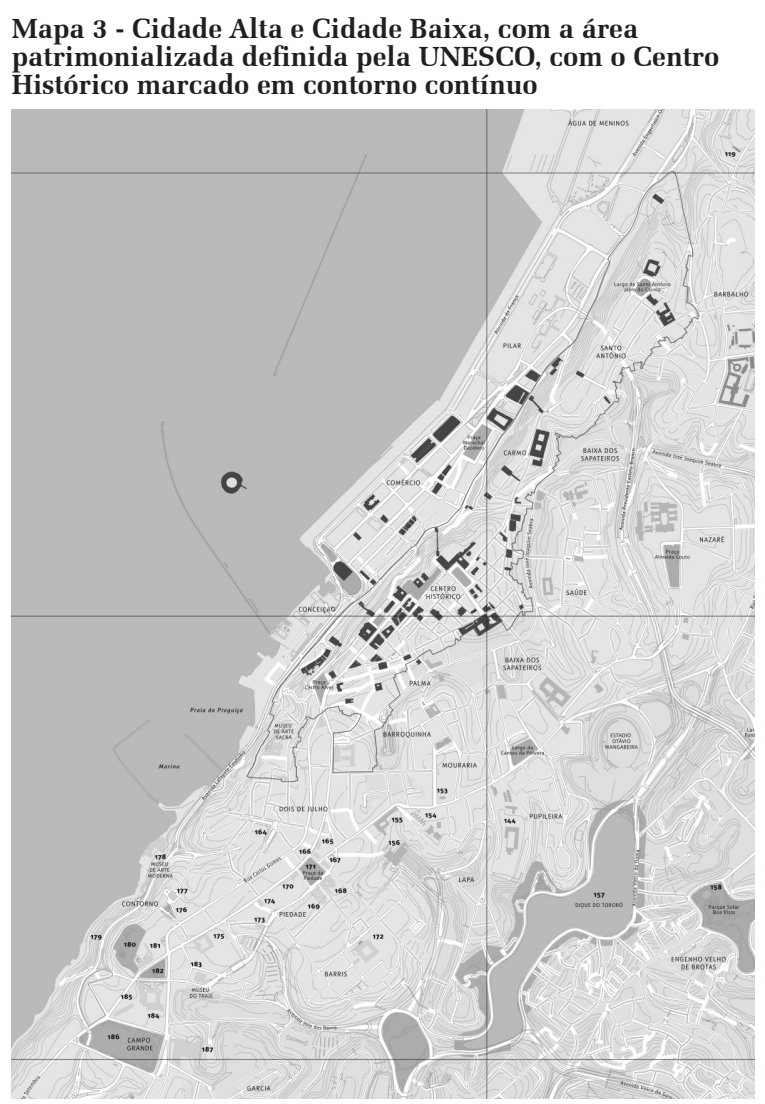

Fonte: (Plano... [20--]).
O início da requalificação do Centro Histórico teve de esperar até depois do terceiro e último mandato de ACM como Governador, para começar sua "recuperação" em 1991, com o impulso dado pelo reconhecimento da UNESCO sobre a importância mundial do Pelourinho como um complexo de arquitetura barroca, o que foi reforçado pelas infusões de dinheiro do Banco Internacional de Desenvolvimento. A maioria dos residentes foi expulsa na operação dessa reconstrução. Porém, com o tempo, tornou-se mais claro que o projeto de reabilitação, em grande medida, deixara a área vazia de pessoas durante as noites, ou seja, tinha desvantagens, mesmo que fosse possível combinar a reconstrução do ambiente com a presença de novos museus, lojas, bares, restaurantes, ONGs, música e performances artísticas. Essas novas ofertas poderiam dar aos cidadãos brasileiros e aos turistas estrangeiros uma visão edificante das origens do Brasil, numa projetada e suposta união cultural e física de europeus, povos indígenas e, acima de tudo, de ex-escravos africanos, representados por seus descendentes, que constituem a parte mais significativa da população da Bahia.

Nesse projeto de reconstruir um patrimônio cultural que dotaria a Bahia de uma identidade histórica privilegiada reside o principal motivo político para a elite branca baiana desejar "restaurar o Pelourinho para a cidade" como um espaço onde orixás africanos poderiam ser celebrados lado a lado dos mosaicos portugueses e dos santos católicos. Por patrocinar publicamente o Candomblé, em vez de reprimir seu culto, e aumentar suas reivindicações de vir a ser uma religião digna de respeito, ACM e sua geração de líderes conservadores não apenas construíram redes mais fortes de controle político populista, mas também reinventaram seu próprio valor como o de uma elite que iria dar para a Bahia uma identidade regional positiva, como um lugar fundacional da nação, e não como um espaço colonial inerte e decadente. 
Porém essa mesma elite viu o Pelourinho como "espaço degenerado" e seus moradores como pessoas com modos de vida e hábitos "patológicos". Como Collins (2015, p. 3) observa, em 1992, a elite e os funcionários do Instituto do Patrimônio Artístico e Cultural (IPAC) do governo do Estado promoveram a "remoção ou reeducação [...] dos moradores moralmente suspeitos”. Eles viviam em estruturas de construções históricas em decomposição, que precisavam ser restauradas para celebrar o caráter afro-brasileiro da Bahia de uma maneira aceitável às sensibilidades das elites brancas.

Essa biopolítica de higienização, defendendo a necessidade de melhorias morais, e de formação para o trabalho, continua a dominar as intervenções do Estado na vida dos soteropolitanos pobres e negros ao longo da periferia urbana de Salvador. É importante não entender a noção de "periferia", aqui, em sua acepção literal, relativa ao espaço. Devido à falta de moradias com preços acessíveis - além das formas específicas de posse de terra e de mercados de propriedade que caracteriza Salvador -, pode-se afirmar que invasões de terra ocorreram em toda a cidade, muitas vezes em áreas ambientalmente problemáticas e nos interstícios de áreas "nobres" e centrais da cidade, onde moram cidadãos mais abastados em condôminos verticais (Souza, 2001). Isso quer $\infty$ dizer que a noção de "periferia" deve ser pens. sada como uma condição social, com a qual as pessoas poderiam buscar formas diversas de สี่ contestação, inclusive, pela afirmação do valor $0^{\circ}$ das identidades sociais racializadas e previa今े mente estigmatizadas, e por meio da própria i. politização de suas culturas populares.

Em nossas pesquisas atuais, buscamos comparar e contrastar as experiências de moradores do Centro Histórico de Salvador com as de residentes de uma grande comunidade formada por uma invasão de terras, num espaço considerado, em outro momento da história da cidade, uma periferia espacial, conhecido hoje pelo nome de Bairro da Paz, localizado numa área economicamente estratégica em termos do desenvolvimento do mais novo "centro" da cidade ao norte, numa zona que era escassamente povoada e ainda coberta por grandes extensões da floresta atlântica quando os invasores começaram a ocupá-la, no final da década de 1970 e início da década de 1980.

À primeira vista, os casos e os contextos aqui comparados parecem e são, em muitos aspectos, radicalmente diferentes. As políticas de patrimônio, incluindo as de patrimônio cultural intangível, permanecem centrais às reviravoltas da reabilitação do Centro Histórico de Salvador, que agora está entrando numa retomada de sua $7^{\text {a }}$ etapa de gentrificação. Uma parte dessa política diz respeito às diferenças entre a cultura popular "vivenciada" pelos moradores originais do Pelourinho, a dos que foram chegando, ou obtiveram permissão para ficar após revitalização dos anos 90, e o tipo de cultura afro-brasileira "popular" que os órgãos do Estado buscaram promover como "patrimônio" depois dos despejos. As discrepâncias de interesses têm sido muitas e os processos de negociação complexos, já que era conveniente, para o Estado, promover o Candomblé, embora muitas famílias do Pelourinho, como as pessoas pobres em toda a cidade, prefiram se voltar para igrejas neopentecostais ao invés de aderir às crenças da religião "africana" (Collins, 2015). No entanto, a política cultural do Estado, que também estava preocupada em tornar o Pelourinho atraente para jovens turistas, provou ser perfeitamente capaz de associar estilos diversos, como o reggae, o hip-hop e o breakdancing, com aspectos claramente promotores dos interesses de uma cultura "afro-baiana" atualizada e popular.

À primeira vista, patrimônio e políticas culturais pareceriam menos obviamente relevantes para o nosso estudo de caso do Bairro da Paz. Porém cabe observar que a cultura popular afro-baiana, manifestada nas formas de música, dança e performance art, é, de fato, central à política de resistência e de reivindicações dessa comunidade (Hita, 2012). Ao falar sobre o Centro Histórico ou o Bairro da 
Paz, verificamos que, em ambos, a "cultura popular”, hoje em dia, é obviamente um produto complexo, resultante de influências locais e transnacionais, que também recebe apoio financeiro e promocional considerável por parte dos órgãos do governo. Juntamente com a exploração comercial, isso propicia práticas de acomodação e cooptação políticas. Mesmo quando é muito comum acontecer, isso não impede que a mesma cultura popular continue a se desenvolver como uma possibilidade e como lócus privilegiado de resistência de subalternos, o que pode, em diversos momentos, ir de encontro às construções oficiais mais higienizadas da identidade afro-baiana e da cultura mercantilista, quando o contexto de performance ou expressão é mais politizado. No caso do Centro Histórico, uma cultura popular não cooptada também tendeu a reafirmar-se de uma forma crítica, enquanto o restante dos residentes da zona, alguns dos quais ganham a vida como artistas e performers, enfrentam novas ameaças de despejo.

Os dois estudos de caso aqui tratados ressaltam a centralidade do que David Harvey (2007) denomina "acumulação por espoliação", no modelo atual e neoliberal de urbanismo em curso. Salvador exemplifica bem os processos de "limpeza social" das principais áreas de "redesenvolvimento", ocupadas por pessoas mais pobres, e os modos pelos quais novas políticas de segurança pública para bairros pobres específicos promovem a extensão de mercados capitalistas. Modelos gerais, entretanto, não ajudam a bem entender como determinadas populações, afetadas por tais projetos de "redesenvolvimento" urbano, reagirão, assim como os efeitos deles ou de suas dinâmicas evolutivas de respostas em mais longo prazo, sejam elas de resistência, resignação ou algo intermediário entre esses dois polos opostos.

A diferenciação socioeconômica interna, juntamente com outras formas de heterogeneidade social e religiosa desses dois lugares, pode influenciar o equilíbrio geral das respostas das comunidades como um todo e, na me- dida em que existem respostas divergentes de diferentes indivíduos e famílias, elas podem vir acompanhadas de conflitos internos substanciais. Para entender as dinâmicas das comunidades empobrecidas afetadas por esses processos e seus diferentes efeitos, é também preciso entender o modo como operam e o tipo de redes sociais mais amplas, políticas e de ONGs, nas quais esses moradores estão inseridos. Harvey (2012) certamente está correto ao insistir que o famoso "significante vazio" de Henri Lefebvre, no seu "direito à cidade", deve ser entendido como um "direito coletivo focado" e não como um direito individual. No entanto, a heterogeneidade social e a divergência dentro das próprias comunidades mais pobres enfatizam os formidáveis desafios políticos mais amplos existentes na própria definição e também na realização das formas de vida social urbana que podem ser mais ou menos satisfatórias para todos em suas variadas diferenças de classe, ocupação, educação, religião, cultura, identidade étnica e gênero. Essa é uma das lições que a etnografia nos ensina, como pretendemos demonstrar na discussão a seguir.

\section{BAIRRO DA PAZ: a cidade formal invadindo o espaço do informal}

Em sua fase mais recente de modernização, Salvador, uma cidade que se aproxima rapidamente do bloqueio total de seu trânsito, está desenvolvendo novos sistemas de transporte, combinando novas rodovias de cruzamentos com sistemas Bus Rapid Transit (BRT) e Veículos Leves sobre Trilhos (VLT), além de uma nova linha do metrô já existente, para conectar parte do antigo centro ao aeroporto internacional, colocando suas pistas e estações no centro da rodovia principal, a Avenida Paralela. O Bairro da Paz está localizado no cruzamento entre essa via e a Avenida Orlando Gomes, transversal que liga a Paralela à Avenida Octávio Mangabeira, que passa pela Orla Marítima (vide Mapa 1). Uma nova estação de 
metrô estava sendo construída, a ser inaugurada em setembro de 2017 , o que significa que novas pistas e viadutos serão também construídos a partir desse novo entroncamento entre as avenidas citadas. Essas obras implicaram a remoção de alguns moradores do Bairro da Paz, mas os novos sistemas de transporte não constituem o único aspecto da situação atual que preocupa alguns de seus atuais moradores, pois eles continuam preocupados com a segurança futura na posse de suas casas.

Toda essa área do Bairro da Paz, onde vivem aproximadamente 60.000 moradores, foi sendo recentemente desenvolvida pela chegada de novos condomínios destinados a grupos das classes médias e altas, o que cria outro tipo de tensão entre esse bairro e a cidade teoricamente "formal", representada pelas vizinhanças mais ricas e os novos condomínios que o circundam. O Bairro da Paz era (e continua sendo) um local significativo para traficantes de drogas (cujos clientes são adolescentes de áreas residenciais da classe média circundante), mas, provavelmente, foi a proximidade desconfortável de uma grande favela das casas de compradores de apartamentos de classe média que motivou o governo estadual a nele instalar uma Base de Segurança Comunitária (BCS) - o equivalente baiano da Unidade de Polícia de Pacificação do Rio de Janeiro (UPP) -, em setembro de 2012.

Embora o comandante da referida Base tenha feito esforços para chegar aos líderes da comunidade - participou de reuniões de organizações comunitárias e tentou atuar como intermediário honesto em muitos dos conflitos, buscando negociar soluções para problemas da comunidade com outras agências estaduais -, sua filosofia policial mostrou ser um tanto autoritária. As relações entre os policiais da Base e os residentes têm sido, muitas vezes, bastante tensas, como resultado não apenas do ressentimento e das queixas gerais da comunidade sobre as práticas racistas e prepotentes como a de parar e buscar agressivamente drogas, de modo indiscriminado, entre os jovens da comunidade -, mas também como resulta- do de alguns incidentes específicos muito sérios que vêm replicando muitos daqueles que minaram a legitimidade das UPPs no Rio de Janeiro (Gledhill, 2015; Gledhill; Hita, 2014).

Além de receber uma Base Comunitária de Segurança, o Bairro da Paz foi escolhido pelo governo municipal de ACM Neto, em 2013, para a implementação de um projeto piloto do novo programa de regularização fundiária para regiões "periféricas" da cidade, o Programa Casa Legal. O relacionamento inicialmente conflituoso com os invasores da área, cuja resistência determinada às tentativas municipais de despejo, nos anos 80, lhe atribuiu o nome original de "Malvinas", foi resolvido depois que o município assumiu a propriedade da terra frente a seus donos privados originais (em troca de cancelamento de dívidas por impostos não pagos). De acordo com a lei municipal de Uso e Ocupação de Terras, em vigor na época, os residentes poderiam ter direito de ocupar a terra em que suas casas foram construídas, mas não teriam os títulos, pois as terras permaneceriam como propriedade pública inalienável. Em um acordo posteriormente assinado (TAC) com o município, líderes da comunidade negociaram, para cerca de 2.000 famílias, o direito de permanecer em uma área central definida (poligonal) nesse assentamento. Foi prometida a entrega de títulos de propriedade de casas - mas não a posse do terrenos - apenas para essas 2.000 famílias (Souza, 2000).

Entre os moradores, afirmava-se que cerca de 500 desses títulos podiam ter sido entregues ao longo dos anos, antes de o Programa Casa Legal (PCL) chegar, embora seja difícil encontrar dados claros sobre essa questão. Além disso, apesar dos compromissos assumidos pelos líderes da comunidade, de tentar limitar o novo assentamento da área para além dessa poligonal, a comunidade continuou a crescer espetacularmente desde o final da década de 1980 e, provavelmente, já conta com cerca de 15 mil casas. Numa estimativa aproximada, assumindo uma média de quatro pessoas por casa, a população total pode ser estimada em 
60 mil. Em contraste com outras grandes favelas de Salvador, como a do Nordeste de Amaralina, localizada entre as áreas residenciais mais ricas, na fronteira com a Pituba, o Itaigara e o Rio Vermelho, cuja extensão era ampliada para cima, o Bairro da Paz expandiu-se quase apenas horizontalmente, já que nele ainda havia bastante espaço desocupado em torno do polígono delimitado, antes da recente onda de construção de condomínios, e também porque seus residentes geralmente não precisaram estender suas casas verticalmente, para além de dois andares, para acomodar novos membros de suas famílias.

No final de julho de 2013, o prefeito ACM Neto visitou pessoalmente a comunidade para distribuir os primeiros dos 500 novos títulos a serem concedidos no âmbito do novo Programa Casa Legal. Um ano depois, "uma concessão de direitos de uso”, que tornaria a ocupação de casas segura (já se divulgava esse fato e viam-se placas indicando que as casas poderiam ser agora vendidas), foi ampliada para o total de 2.500 famílias, como foi noticiado em jornais. No entanto, como esse número é claramente inferior ao do total de casas familiares instaladas no Bairro da Paz, o então líder da organização representativa mais inclusiva da comunidade, nesse momento, o seu Fórum Permanente de Entidades Sociais do Bairro da Paz (FPEBP), expressou preocupação com as implicações desse processo de regularização da ocupação da terra em uma área de especulação imobiliária tão intensa. A gravidade dessa questão foi recentemente ressaltada para a já acuada e assustada comunidade, diante do assassinato de conhecido agente imobiliário, a mando de outro rival, com o qual disputava a legalidade da propriedade do mesmo terreno, em terras próximas ou dentro da esfera do que era considerado ser parte do bairro.

Esse crime ocorreu em terras que a vítima prometera doar à comunidade do Bairro da Paz para edificação de uma área coletiva de lazer, demandada há anos por suas lideranças. Também, por isso, moradores do BP suspei- tam haver uma agenda oculta por trás desses interesses no uso da terra, chegando suas lideranças, inclusive, a denunciar, durante o segundo semestre de 2017, um novo projeto de privatização e venda de um terreno reivindicado à Prefeitura pelo bairro, para construção de uma nova escola. Outra preocupação é a possibilidade de a Prefeitura vir a desejar expulsar outras famílias, alegando que suas casas foram construídas em zonas de alto risco ambiental, como já vem acontecendo com aquelas instaladas na zona do Beira Rio, onde mais de 40 outras famílias foram notificadas a sair, em concordância com uma política já implementada em outras áreas. Embora as casas sejam frequentemente construídas em lugares inseguros em Salvador e, por vezes, algumas delas tenham desmoronado com as chuvas intensas, as soluções de engenharia civil, que tornam os edifícios existentes seguros em regiões inclinadas, parecem ser aplicadas de forma um tanto quanto seletiva, nunca para dar maior segurança aos mais pobres que moram em áreas de risco. Outra reclamação dos moradores diz respeito ao processo de regularização que estava acontecendo na ausência das melhorias de infraestrutura urbana que a lei federal estipula como precedentes à entrega desse tipo de titulação. Uma vez que até as principais ruas da comunidade sofreram inundações naquele ano, esse ponto de vista atraiu um apoio considerável de moradores em uma reunião comunitária em que o pároco endossou firmemente expressões de dúvida e ansiedade frente às reais intenções e às metas programadas pela Prefeitura. No entanto, o processo de entrega da titulação de casas continuou avançando independentemente do apoio de seus líderes. Em março de 2015, quando o prefeito ACM Neto visitou novamente a comunidade para entregar mais 617 títulos pessoalmente, ele não só afirmou que o programa de titulação estava alcançando a meta prometida, como também anunciou novos trabalhos para lidar com deficiências de drenagem e pavimentação de estradas (Correio da Bahia, 15 de março de 2015). 
No entanto, de acordo com a informação distribuída entre os participantes do FPEBP por conselheiros de oposição, incluindo o vereador Waldir Pires - responsável, como governador do estado, entre 1987 a 1989, pelo acordo original que levantou a ameaça de despejo da invasão das Malvinas -, essas, como outras promessas anteriores, não foram cumpridas. As melhorias prometidas, como a remodelação da clínica de saúde e a construção de uma área de esporte e lazer ao lado da Escola Nossa Senhora da Paz, não foram realizadas ou, no caso do atual posto de saúde, apenas houve uma leve pintura nas paredes, o que não se explica, na visão de lideranças e de muitos moradores, diante da quantia indicada no orçamento oficialmente alocado ao projeto.

O FPEBP, criado em 2007, atua em paralelo com o Conselho de Moradores do Bairro da Paz e procura agregar diferentes grupos políticos e religiosos e organizações culturais que ali atuam, além de fornecer espaços novos para a organização popular e atuação de suas principais lideranças comunitárias (Gledhill; Hita, 2014). Procura produzir seus próprios diagnósticos (de baixo para cima) sobre as principais necessidades e problemas da comunidade. Busca negociar suas demandas com as autoridades, convocando todos os moradores para audiências públicas, nas quais se solicita que funcionários públicos expliquem suas poㄱ. líticas, respondam às queixas e ouçam o que moradores comuns pensam ser importante para สี่ atender a suas necessidades, apresentando, i também, o modo de desenvolvimento local pre今े tendido. Organizam-se ainda eventos culturais i. e educacionais destinados a combater a "estig-

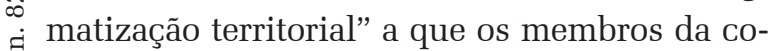
ले munidade estão sujeitos (Wacquant, 2007). grandes assentamentos irregulares no Brasil, um lugar socialmente heterogêneo, distinguindo-se de outros bairros pela elevada presença de diferentes igrejas e organizações culturais (Hita; Gledhill, 2010). Muitos moradores têm empregos fora da comunidade, e um número crescente está estudando em universidades, mas há também uma grande quantidade de atividades econômicas de pequena escala no interior do bairro, empresas familiares bem-sucedidas e cooperativas que receberam apoio do governo e da Petrobras, até antes da crise dessa empresa estatal. O fato de os residentes do Bairro da Paz terem de lutar duro para manter seu "direito à cidade" produziu uma comunidade que, até hoje, é reconhecida por sua forte capacidade de organização e por também ter atraído várias ONGs, incluindo a Santa Casa de Misericórdia e, antes dela, a ONG Jesuíta "Centro de Estudos e Ação Social” (CEAS), que contribuíram bastante e ainda o fazem para a preparação de líderes comunitários - aqueles que possuem habilidades para saber enfrentar e discutir efetivamente com funcionários do Estado.

Outro aspecto diz respeito às relações entre criminosos e moradores, que têm sido complicadas. Houve um período em que os próprios criminosos assumiram a responsabilidade pela resolução de litígios e pela redução de roubos e crimes sexuais dentro da comunidade. ${ }^{4}$ Depois, estourou uma guerra de drogas pelo controle do Bairro, a qual, juntamente com a violência anteriormente mencionada associada aos promotores imobiliários, cujos seguranças, armados, às vezes ameaçaram alguns moradores -, produziu uma desativação temporária do FPEBP, antes de a Base chegar. A maioria dos líderes da comunidade expressou pouco entusiasmo verbal pela instalação de uma BCS no bairro, embora, inicialmente, eles não tivessem capacidade de fazer nada, tampouco condição de impedir essa medida.

Essa desativação do FPEBP, naquele momento, pode ter sido uma resposta conveniente para enfrentar a inevitável chegada da Base, à qual não poderiam mais se opor. Seus líderes também tiveram a compreensão de que, com as eleições locais próximas, os conselheiros políticos do BP já mostravam sua ansiedade

${ }^{4}$ Esse regime foi baseado explicitamente no modelo do Primeiro Comando da Capital (PCC) de São Paulo (Feltran, 2010). 
em poder se dedicar às campanhas políticas, preocupados que estavam em poder eleger alguma das lideranças populares e "autênticas" da comunidade para o cargo de vereador. No entanto, até o final de 2012, a chegada da BCS provocou reações negativas em muitos dos moradores e o cronograma avançado de obras a serem realizadas pela Companhia de Desenvolvimento Urbano do Estado da Bahia (CONDER) e pela empresa privada OAS deixou claro que algumas famílias que moravam no Bairro da Paz desde a década de 1980 perderiam suas casas como resultado da criação de novas pistas e ampliação das existentes, ligadas à construção da nova estação de metrô e à criação de novas linhas de BRT. Tudo isso e o anúncio do programa de regulação fundiária Casa Legal desencadearam um ciclo novo e frenético de atividades do FPEBP, que voltou a funcionar em 2013, depois de um ano parado.

Setenta e cinco famílias receberam notificação para sair até o final de 2014, mas outras expulsões, além dessas, eram esperadas. O FPEBP tentou intermediar as relações entre as famílias, a OAS e a CONDER, não apenas para ajudar os moradores, mas para tentar tornar mais transparente e aberto o processo de negociação entre os indivíduos afetados e os burocratas do governo estadual. O envolvimento de líderes comunitários incentivou as partes expropriadoras a oferecerem programas compensatórios que beneficiariam os moradores que não seriam despejados, como a "contrapartida social” por conta da perda material e social que seria criada localmente por trabalhos de engenharia projetados para beneficiar uma população urbana mais ampla e os visitantes da cidade.

De acordo com as entrevistas realizadas por nossa equipe com as famílias afetadas, as negociações com a CONDER e a OAS sobre os valores a serem recebidos em compensação pela perda de casas não foram, de fato, baseadas em princípios gerais transparentes, mas em uma consideração caso a caso, definidas de modo individual. Um valor médio dessas inde- nizações mencionadas foi em torno de 15.000 reais (cerca de 4.000 dólares americanos no momento em que os pagamentos foram acordados), dependendo do tamanho da casa e dos materiais de construção utilizados. Aparentemente, alguns estabelecimentos comerciais maiores receberam substancialmente mais, embora proprietários e moradores que sabiam mais sobre isso relutassem em querer especificar esses números. Os líderes comunitários não receberam informações claras sobre a escala de despejos futuros, mas foram convidados a discutir o que pareceu ser um fluxo cada vez maior de projetos que estão sendo oferecidos à comunidade, de cima para baixo. Muitas dessas propostas não foram realmente de grande interesse para a população local, e a situação em que o FPEBP agora se encontrava era muito diferente do modo como ele costumava operar e reagir nos processos de negociação anteriores, quando os membros da comunidade identificavam necessidades, definiam as maneiras de atendê-las, debatiam e estabeleciam prioridades e, finalmente, as apresentavam como demandas ao governo, através de reuniões públicas abertas, de baixo para cima, e não ao contrário, como começou a acontecer nessa nova fase.

No entanto, apesar das tentativas frustradas de organizar encontros com funcionários da CONDER e da OAS - muitos dos quais, frequentemente, foram cancelados à última hora pelas autoridades -, cabe mencionar que muitos dos líderes do Bairro da Paz estavam agora muito mais firmemente inseridos na maquinaria da política partidária, como conselheiros de vereadores e de outros políticos, embora nem sempre à esquerda do espectro político. Em vários casos, houve um forte envolvimento com o movimento negro. Mas também houve suficiente confiança em possibilidades de conseguir algo através de canais políticos institucionalizados para incentivar os líderes do Bairro da Paz a mudar o foco para ver quais as melhorias nos serviços e na infraestrutura que poderiam negociar para sua comunidade, como 
compensação pelos despejos, para além de se concentrarem na defesa dos direitos e interesses das famílias que realmente foram despejadas ou deslocadas para outras áreas da cidade.

Existe uma clara diferença entre a postura dos líderes do Bairro da Paz na conjuntura de 2015 e a que eles e o FPEBP adotaram em 2010. Reagindo a reportagens dos jornais que mostravam como os planos da administração do prefeito anterior, João Henrique Carneiro, para a requalificação urbana e a regularização da posse da terra ameaçavam deslocamentos em grande escala de pessoas de comunidades mais pobres, e não apenas pobres, e preocupadas diretamente com as implicações dos planos para melhorar os sistemas de transporte público em preparação para a Copa do Mundo, as lideranças do Bairro da Paz submeteram funcionários públicos convidados, a um interrogatório bastante agressivo, no que foi considerada uma bem sucedida audiência pública convocada pelo FPEBP, da qual representantes de outras comunidades locais também participaram. Nessa conjuntura, o Bairro da Paz desempenhou um papel central na união entre vários movimentos sociais e políticos preocupados com a atual direção das próximas transformações urbanas e o seu caráter socialmente excludente. Durante um par de meses, as reuniões do FPEBP estiveram cheias de políticos

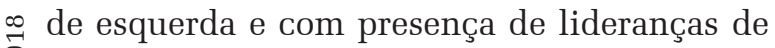
సे outras comunidades. Algumas outras comuì nidades tentaram adotar o modelo do Fórum ฮี่ das Entidades. Mas parece que, quando ficou i claro que não havia plano algum para realizar 今े uma remoção em grande escala de moradores i do Bairro da Paz, os líderes se tranquilizaram e

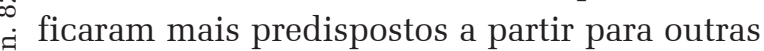
ì negociações mais pragmáticas.

Podemos dizer, em defesa desse pragmatismo, que parte dessas lideranças argumentava e também estava consciente de que nem todas as famílias a serem despejadas do Bairro da Paz eram constituídas de moradores de longa data nessa comunidade, que perdiam seu patrimônio pessoal, e, por isso, nem todos tinham o mesmo direito de permanecer. Elas se mostraram incomodadas com o fato de alguns parecerem ter invadido a nova área a ser despejada depois das notificações, precisamente porque já sabiam que seriam removidos, no intento de negociar algum tipo de pequena indenização.

Caso semelhante é o do Centro Histórico, onde alguns moradores despejados aceitaram o pagamento de indenização e, em seguida, se realocaram em outro prédio em área diferente, ainda não despejada. Dificilmente podemos nos surpreender quando pessoas, obrigadas a se precipitar, para abrir seu caminho no mundo, se negam a jogar as regras que os mais poderosos formularam para terceiros, e não as praticam. De fato, essa forma de "resistência dos mais fracos" é uma característica comum de pessoas classificadas como "vulneráveis", naquilo que Loïc Wacquant chama de a "mão esquerda” intervencionista, biopolítica, do estado neoliberal, cuja mão direita repressiva é a do policial e do regime prisional dedicado a "punir os pobres", mantendo-os no seu devido lugar (Wacquant, 2009).

Tampouco podemos afirmar que os líderes, no Bairro da Paz, estejam se tornando sujeitos “dóceis", de "governança neoliberal”. Quando as melhorias de infraestrutura prometidas e por eles exigidas não se materializam, eles não hesitam em ocupar a Avenida Paralela para protestar, causando grande caos, com engarrafamentos que afetam várias zonas de toda a cidade, por ser essa via uma de suas principais artérias. Muitos deles são ativos na promoção e criação de novas oportunidades educacionais para jovens da comunidade (o que inclui o aumento do número dos que podem estudar na Universidade Federal e outras universidades privadas). A oferta escolar inadequada continua a provocar indignação em seus moradores e líderes. Eles são bastante céticos sobre as táticas adotadas pela administração de ACM Neto e, em particular, sobre o real valor do projeto "Parque Social", que foi apresentado como a principal "contrapartida social" para compensar os impactos negativos dos projetos de mobilidade urbana. 
O Parque Social se concentra em promover atividades de "empreendedorismo social" e capacitação de pessoas de baixa renda para “participar” na sociedade, algo que já existe e é promovido em demasia pelas ONGs e entidades que já atuam no bairro, o que lhes retira possibilidades de obtenção de recursos. O Parque é dirigido pela mãe do atual prefeito, a psicóloga Maria do Rosário Vianna de Magalhães. A maioria dos moradores sente que as melhorias em infraestrutura, ruas, espaços públicos e ambientes construídos, bem como em instalações de saúde pública e lazer, são mais importantes e correspondem ao tipo de contrapartida, de fato, exigida por eles. Não desejam receber novos programas de treinamento de qualidade duvidosa e que não parecem atender às reais demandas de seus atuais moradores e lideranças. Esse tipo de programa, imposto de cima, está, na maioria das vezes, pouco relacionado com as habilidades de trabalho e de subsistência que as pessoas realmente possuem. Além de partirem de enquadramentos estereotipados de raça e (ou) classe, não correspondendo às aspirações de pessoas pobres para sair de condições de pobreza, ou lhes fornecer um suporte verdadeiramente relevante para isso, são programas assistencialistas que mais beneficiam os empregados nessas instituições do que atendem às necessidades de seus públicos-alvo.

Até agora, pelo menos aquelas propostas vistas como imposições vindas de cima continuaram a ser criticadas e são alvos de resistências, pois são consideradas como falsas promessas que continuam desafiando as combativas lideranças. O déficit orçamentário crescente do município torna improvável que seja alcançado muito mais em um futuro próximo, embora haja ainda margem para a discussão continuada sobre os tipos de investimentos que os moradores do bairro preferem. O tipo de análise aqui feito também se aplicaria ao caso do Centro Histórico, onde parece haver oportunidades, hoje, para se evitar a repetição de algumas das injustiças do passado, mas também existe uma probabilidade contínua de que os antigos moradores ain- da existentes sejam removidos para tornar esses espaços disponíveis para outras classes sociais os habitarem.

\section{REFAZER, DE NOVO, O CENTRO HISTÓRICO DE SALVADOR}

O plano de ação elaborado em 1991 pelo IPAC para a "recuperação" do Centro Histórico de Salvador focalizou uma área central (vide Mapa 3) que continha o maior número de edifícios coloniais e barrocos (Mourad, 2011). No esquema do IPAC, o interesse foi voltado para os edifícios. Neles, as pessoas acomodaram suas residências em ruínas constituídas de casarões abandonados, que outrora foram mansões ocupadas por famílias da elite, que, no século XIX, se transportaram para distritos novos, como a Graça e a Vitória. E esses novos moradores do Centro Histórico foram tratados como uma ameaça para o patrimônio arquitetônico, pelo que precisavam ser removidos (Collins, 2015).

O projeto foi dividido em sete etapas, definidas pelo grupo de edifícios a serem restaurados e os novos usos atribuídos aos prédios restaurados e aos espaços públicos a eles associados. O uso residencial de propriedades reconstruídas não foi previsto até a quarta etapa. Embora tenha havido algum foco em atividades artísticas no planejamento para a segunda etapa, o turismo, as compras e a construção de hotéis foram mais proeminentes até a sexta etapa, o que incluiu mais projetos culturais "populares", como uma "Praça Reggae". A sétima etapa, programada para começar em 2002, foi definida em termos de "uso misto", incluindo o uso residencial, embora outro grande parque de estacionamento para compradores e turistas também fizesse parte dessa reabilitação, planejada para treze blocos (Mourad, 2011, p. 7).

Durante os estágios de requalificação, que foram realizados na década de 1990, agora mais notórios, milhares de moradores (por volta de 3.000) da zona central do Pelourinho 
foram socados em caminhões e encaminhados para a periferia urbana (Fazenda Coutos), com pequenos pagamentos de compensação, de modo que suas antigas casas pudessem ser, agora, transferidas para novos usos ou novos usuários (Bittencourt; Carneiro, 2015; Montoya Uriarte, 2012). É importante reconhecer, como mostra Collins, que as "vítimas" desse despejo em massa não falharam inteiramente em "agência", apesar de terem sido submetidos a um aparelho estatal altamente coercitivo, cuja "mão esquerda", constituída de profissionais de saúde e trabalhadores sociais, os considerava como degenerados que precisavam de ajuda e higienização. Enquanto isso, a "mão direita", sob a forma de um batalhão da polícia militar, foi encarregada de assegurar que essas pessoas não resistissem ao despejo, ou tentassem retornar às suas casas anteriores, processo que adquiriu reputação na cidade toda pelo intransigente uso da violência. Assim, eles não podiam desafiar com sucesso esse sistema, embora alguns deles conseguissem garantir melhores resultados pessoais manipulando (ou mesmo chantageando) funcionários, ou buscando o apoio de trabalhadores de ONGs.

Nem todos os despejados e indenizados deixaram a área imediatamente, embora a expulsão da grande maioria dos residentes originais do Pelourinho não pudesse ser adiada inde$\infty$ finidamente. Havia momentos em que aqueles ㄱ. que eram "educados" pelos serviços atenciosos ensinavam a seus superiores alguma lição séria. ฮี Essa situação talvez possa ser mais vividamente ilustrada com a narrativa etnográfica de Collins के sobre o caso de uma mulher usuária de drogas, i. Topa. Na palestra de uma enfermeira sobre higiene, cuja recomendação era a de evitar defei car na rua, educadamente ela lhe perguntou, irônica e hipoteticamente, o que aconteceria se, enquanto ela fosse praticar sua atividade habitual de procurar coisas úteis no lixo, na área onde essa especialista em saúde morasse, ela precisasse usar o banheiro e se batesse na sua porta para solicitar isso... (Collins, 2015, p. 285) - Sua empregada, por acaso, a deixaria entrar?
Uma atenção etnográfica mais cuidadosa sobre quem eram as pessoas despejadas, revela, de modo nada surpreendente, antes a heterogeneidade socioeconômica do que uma condição totalmente uniforme de abjeção. O caráter "boêmio" do lugar, imagem criada pela contínua intimidade de uma elite agora não mais residente e os habitantes locais dos bares e bordéis, parece ter atraído também alguns migrantes de classe baixa da periferia urbana, que estavam à procura de um ambiente que fosse social e moralmente menos constrangedor do que outros bairros "populares", que permaneceram bastante conservadores em termos de questões como os da preferência sexual. Embora houvesse mais envolvidos em atividades para além daquelas do trabalho sexual no Pelourinho antigo, também era esse um lugar que oferecia às mulheres os serviços sexuais como uma alternativa de melhor remuneração do que o serviço doméstico, mal pago e percebido por muitas delas e por pessoas de baixa renda como difícil de distinguir da escravidão. As expulsões em massa, na década de 1990, provavelmente criaram uma impressão indelével em outros soteropolitanos que viviam do que eles percebiam como circunstâncias precárias. Porém, no momento em que a sétima etapa do programa de reconstrução foi iniciada, o Estatuto da Cidade reforçou os princípios já consagrados na Constituição de 1988 em relação ao direito social à habitação e criou-se a necessidade de consulta e participação popular no processo de planejamento que a máquina carlista tinha tão obviamente ignorado durante os estágios anteriores. As autoridades da cidade e do governo do Estado também agora tiveram de lidar com o apoio oferecido por ONGs mais radicais aos moradores das áreas urbanas sujeitas à requalificação. No caso do Centro Histórico, foi formada, em 2001, uma nova Associação de Moradores e Amigos do Centro Histórico (AMACH), com o apoio do Centro de Estudos e Ação Social (CEAS), de origem jesuítica, a mesma organização que já havia apoiado os moradores do 
Bairro da Paz em suas lutas contra o despejo e, posteriormente, trabalhou com grupos juvenis e culturais naquela comunidade. Como resultado de uma luta prolongada, a AMACH, finalmente, em 2005, conseguiu um novo acordo formal, um Termo de Ajustamento de Conduta (TAC) assinado por representantes do Ministério Público da Justiça, do governo estadual e da CONDER (Bittencourt; Carneiro, 2015; Montoya Uriarte, 2012). Isso garantiu o direito de 103 famílias residentes (e que já eram 108 em 2016) de permanecerem na área, prometendo uma nova prioridade para a participação da comunidade no planejamento das novas unidades residenciais a serem construídas e dos espaços públicos associados. No entanto, as declarações públicas da AMACH logo reclamaram que o IPAC e a CONDER não estavam levando a sério as consultas e a participação dos moradores nessa nova fase do projeto (Montoya Uriarte, 2012). Passados 12 anos desse TAC, apenas $70 \%$ das famílias foram relocadas em casarões, em péssimas condições de habitação, segundo uma nova perícia realizada pela AMACH por peritos da Faculdade de Arquitetura da UFBA, em 2017 (AMACH, 2017).

Os moradores não tiveram oportunidade de opinar sobre o tamanho dos apartamentos e a configuração dos prédios reconstruídos onde iriam reorganizar sua vida familiar e social, após um período de deslocamento. O IPAC e a CONDER não só pareciam estar demasiadamente preocupados com as necessidades do parque de estacionamento planejado, como tampouco consultaram os moradores sobre o projeto de creche que eles propuseram instalar, o que levou à rejeição definitiva de parte do projeto por parte da AMACH (Montoya Uriarte, 2012). Os planejadores e os arquitetos pareciam não ter noção alguma do impacto que seus projetos teriam sobre a vida das famílias afetadas e as relações delas com seus vizinhos. Para criar um lugar que as pessoas realmente desejam e possam habitar, é preciso recriar a sociabilidade de um espaço comum, um espaço que tenha vida própria, para além de transformá-los em espaços das compras e do consumo da cultura como espetáculo. Pior ainda: os planejadores não pareciam se importar muito com esse tipo de questão.

Muitos dos que conseguiram permanecer morando nas regiões próximas do Pelourinho, com frequência estavam envolvidos em atividades musicais, artísticas e artesanais, ligados a um passado mais "boêmio" e, talvez por isso, foram percebidos pelas autoridades como portadores de algum valor adicional para o lugar, em termos do interesse turístico, e como representantes de "identidades afro-baianas", na visão oficial. Foi essa a parcela dos moradores que recebeu maiores incentivos para seu desenvolvimento, à medida que novos gêneros de música negra e eventos de cultura popular se tornaram cada vez mais centrais nos anos seguintes para a promoção comercial e governamental da Bahia. Esse tipo de perfil também lhes permitiu obter apoio e patrocínio de muitas ONGs que se localizavam e outras novas que foram se instalando no Centro Histórico restaurado. No entanto, a preferência oficial pelo despejo continuou a dominar os mais recentes esquemas de revitalização de outras áreas do Centro Histórico que estão além do seu centro, situado na região do Pelourinho, como as do Bairro 2 de Julho, do Carmo, de Santo António além do Carmo, e do Pilar.

Serpa (2017) registra que os artesãos que trabalham em edifícios antigos, na área da Ladeira da Conceição, estão sendo pressionados a sair pela Secretaria Municipal de Urbanismo (SUCOM) e pelo Instituto Federal de Patrimônio Histórico e Artístico (IPHAN), sem qualquer garantia de indenização ou realocação, mesmo que suas atividades artesanais, como a escultura e a pintura de ícones utilizados no Candomblé, constituam ainda uma parte indiscutível do Patrimônio Cultural Intangível da Bahia. Um grupo de artistas de teatro que ocupou a Vila Coração de Maria, no Bairro do Dois de Julho, por quatro décadas, agora está ameaçado de despejo por uma Confraria da Igreja Católica (a Irmandade São Pedro dos 
Clérigos), que quer substituir suas casas pelas de um edifício novo, destinado a produzir novo parque de estacionamentos para essa região. Como foi observado por Serpa (2017) e Mourad, Figueiredo e Baltrusis (2014), esses exemplos são simplesmente a ponta de um iceberg em termos de projetos e planos atualmente em cima da mesa dos planejadores.

Os artistas e intelectuais, que tendem a estar na vanguarda e na defesa desses espaços remanescentes de uma mistura social, em um ambiente que retém o charme de um patrimônio histórico vívido, conseguem continuar protestando, geralmente de maneira criativa e imaginativa. Mas esses protestos não impedem o avanço dos crescentes e agressivos processos de "gentrificação" decorrentes da criação de apartamentos de luxo em casas vendidas por moradores de classe baixa para as empresas construtoras. Os especuladores agora adquiriram os títulos de uma grande quantidade de propriedades decadentes, e prometem aos futuros e mais afluentes moradores o acesso a vistas espetaculares para a Baía de Todos os Santos (Mourad; Figueiredo; Baltrusis, 2014), nas proximidades dessa mesma região do Bairro 2 de Julho, nomeado como o Cluster de Santa Tereza. Por sua vez, um dos problemas que decorrem de propriedades que ficam em um estado perigoso de deterioração, enquanto se

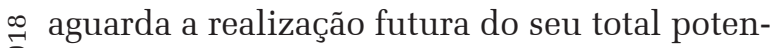
ণ cial de desenvolvimento, é que as paredes e a alvenaria em colapso, muitas vezes, matam ou . mutilam os transeuntes durante fortes chuvas. i No entanto, seu valor futuro parece certo e ले seus donos conseguem se aproveitar da impui. nidade quando as coisas não dão certo.

Embora o processo de expulsão das áreas do Centro Histórico que ainda aguardam a sua restauração possa não ser tão espetacular quanto os despejos em massa do Pelourinho da década de 1990 (até porque a grande maioria já foi expulsa anteriormente), um processo de "limpeza social" já se encontra novamente em andamento. O planejamento de baixo custo e as abordagens coercitivas para a remoção de atores sociais, cuja presença é incompatível com esses planos, continuam constituindo a regra, e não a exceção, na reconfiguração do espaço urbano de Salvador. Apesar de a habitação social ser incluída em alguns projetos patrocinados pela atual administração da cidade, sua principal prioridade é maximizar os potenciais valores imobiliários e a gentrificação de suas áreas.

\section{CONCLUSÃO}

As intensas mobilizações ocorridas em 2010 contra processos de requalificação urbana que pareciam ser um perigo real e presente de despejos em massa, em diversas zonas da cidade, não voltaram a se repetir com a mesma intensidade em Salvador, mesmo que tenham sido marcantes e significativas as manifestações de estudantes da cidade, que se juntaram aos protestos nacionais do Passe Livre em 2013, e as do pós-impeachment de Dilma Rousseff. Contudo não foram elas motivadas pela luta pelo direito à cidade. Tampouco devem ser lidas como indicação do grau de satisfação das pessoas que habitam os espaços socialmente periféricos da cidade sobre o tipo de "direito à cidade" de que atualmente desfrutam. Estar preso em engarrafamentos é inconveniente para todos os soteropolitanos, mas apenas alguns deles podem evitar viajar nos ônibus que estão crescentemente sujeitos a assaltos e que frequentemente falham em fornecer um serviço adequado aos mais pobres. A coleta inadequada de lixo bem como a falta de drenagem adequada e de saneamento adquirem uma significância maior por aumentarem as chances de os soteropolitanos pobres virem a ser infectados por epidemias, como Chikungunya, Dengue ou Zika. Grandes investimentos do governo da cidade nas sofisticadas zonas à beira-mar, do Rio Vermelho e da Barra, muito frequentadas pelos turistas, contrastam com o lento progresso das melhorias de infraestrutura prometidas na periferia urbana. 
Políticas que são coercitivamente paternalistas, na melhor das hipóteses, violentas e racistas, na pior das hipóteses, servem para lembrar às pessoas que, por mais que trabalhem e por muito que se dediquem à família e à igreja, elas ainda continuarão sendo consideradas como uma "ameaça" por setores afluentes da sociedade, numa cidade que é, cada vez mais, compreensivamente securitizada. É impossível viver em cidades brasileiras sem se dar conta, diariamente, de suas desigualdades. Na cidade securitizada do capital imobiliário, as desigualdades estão cada vez mais ancoradas no próprio ambiente construído. Antes do século XIX, os patrões e os escravos do Pelourinho, pelo menos viviam nas mesmas casas, embora em pisos e em espaços domésticos separados, encontrando-se na rua. Esse não parece ser mais o modelo incorporado no planejamento da vida do atual Centro Histórico "revitalizado".

Contudo é importante perceber que a quantidade considerável de compras de terrenos e propriedades que o setor privado está realizando tem sido feita de modo discreto e que ainda não tem resultado em grandes projetos de requalificação urbana, ou na produção de novos mecanismos de mercado, que costumam ser acompanhados por medidas mais coercitivas. É crucial reconhecer também que esses processos de mercado estão acontecendo, inclusive, em mercados informais, já que também existem em "assentamentos irregulares”. Eles são igualmente constrangidos, em Salvador, pela frequência com que a terra ocupada pertence ao município, mas as casas que receberam títulos de posse não são inalienáveis. O futuro de lugares como o Bairro da Paz poderia ser considerado como uma espécie de "gentrificação de baixo nível”, se for considerada a base da remoção de moradores de áreas de risco ambiental e a tendência crescente a uma concentração de propriedade cada vez maior nas mãos de novos moradores com melhores empregos e maiores rendimentos. Isso, de fato, é o que muitos dos seus atuais morado- res já desejam para o maior desenvolvimento futuro do bairro.

A restauração de bairros antigos e sua ressignificação como patrimônio cultural nem sempre precisa ser um processo socialmente excludente: se, de um lado, os museus e os monumentos não são apenas gratuitos para visitas, por outro, podem falar sobre interesses de todos. E as atividades culturais têm um apelo popular suficiente para atrair uma ampla audiência e, também, garantir a participação imediata de vários grupos distintos. Novas modalidades de "espaços públicos", criadas por esse tipo de revitalização urbana, poderiam vir a se tornar espaços de encontro de diferenças, e não apenas espaços de exclusão (Leite, 2006). Os turistas também podem se tornar parte de tais encontros. Mas onde os distritos reconfigurados se tornam locais de moradia permanente para uma nova população, abastada e profissional, e as facilidades oferecidas são de luxo com fins lucrativos, mesmo que o acesso a tais espaços "gentrificados" não seja restrito fisicamente por guardas de segurança, a maioria dos serviços oferecidos é inacessível a pessoas abaixo das classes média e alta, impossibilitando ou constrangendo sua circulação.

O "problema urbano", hoje em dia, reside principalmente em saber se um número significativo de cidadãos continuará a ser excluído do gozo de uma vida urbana decente e, ainda, saber se a defesa dos privilégios das classes médias e altas produzirá ainda mais cidadãos excluídos, caso as forças e os grupos que se empenharam em derrubar Dilma Rousseff, em 2016, conseguirem implantar suas políticas radicais de maior austeridade neoliberal. Dada a lógica vigente de padrões de desenvolvimento urbano, impulsionada pela acumulação de capital imobiliário e pela especulação, há um perigo crescente de que novos despejos de cidadãos mais pobres sejam priorizados em lugar de se promover uma verdadeira reabilitação urbana, na qual uma real urbanização de assentamentos irregulares seja realmente executada, apesar das décadas de promessas 
não cumpridas. O objetivo da política pública deveria ser o de eliminar "a periferia”, ao invés de movê-la para outro lugar, fora da vista e fora da mente dos mais abastados.

Mas a resistência efetiva à "acumulação por espoliação” exige solidariedade entre atores socialmente diferenciados, cujos interesses imediatos podem não ser convergentes, como vimos no caso do Bairro da Paz, apesar do nível relativamente alto de organização comunal transversal que o caracteriza. Essa solidariedade não se desenvolverá de forma totalmente espontânea e sem algum trabalho político para isso, mesmo que a crise aprofundada aumente o ressentimento subjacente à desigualdade social grosseira existente na sociedade brasileira. Mas é mais provável que ela se desenvolva se as pessoas se concentrarem sobre os problemas em seu conjunto e estiverem dispostas a dialogar seriamente, em primeiro lugar, sobre o tipo de cidade que, mesmo que continue desigual em termos do tipo de diversões que oferece a diferentes classes, poderia pelo menos ser feita de um modo muito mais satisfatório e democrático para todos; e, em segundo lugar, caberia pensar como refazer essa cidade e mantê-la através de novos acordos políticos, administrativos e legais mais equitativos.

Recebido para publicação em 17 de outubro de 2017 Aceito em 30 de novembro de 2017

\section{REFERÊNCIAS}

Sో ASSOCIAÇÃO DE MORADORES E AMIGOS DO CENTRO HISTÓRICO DE SALVADOR (AMACH). Pericia popular no

‥ Centro Histórico de Salvador: avaliação das condições de

i vida dos habitantes vulnerabilizados pelo descumprimento

$\therefore$ da TAC da $7^{\mathrm{a}}$ etapa. Salvador: AMACH:UFBA, 2017. 123 p.

๓ं BITTENCOURT, D.; CARNEIRO, J. Luta e resistência dos

× moradores pelo direito à moradia em áreas de patrimônio

î cultural: a formação de uma esfera pública. Salvador: Edufba, 2015. $177 \mathrm{p}$.

CALDEIRA, T. P. R. City of walls: crime, segregation and citizenship in São Paulo. Berkeley: University of California I Press, 2000. 487 p.

CARDOSO, M. A. de S. S. Como morre um projeto de policiamento comunitário: o caso do Cantagalo e do PavãoPavãozinho. 2010. 344 f. Tese (Doutorado em Antropologia) - Universidade de Brasília, Brasília, 2010.
COLLINS, J. F. Revolt of the saints: memory and redemption in the twilight of Brazilian racial democracy. Durham: Londres: Duke University Press, 2015. 480 p.

DANTAS NETO, P. F. Tradição, autocracia e carisma: a política de Antônio Carlos Magalhães na modernizacão da Bahia (1954-1974). Belo Horizonte: Universidade Federal de Minas Gerais, 2006. 587 p.

FAULHABER, L.; AZEVEDO, L. SMH 2016: remoções no Rio de Janeiro olímpico. Rio de Janeiro: Mórula Editorial, 2015. 124 p.

FELTRAN, G. de S. Crime e castigo na cidade: os repertórios da justiça e a questão do homicídio nas periferias de São Paulo. Caderno CRH, Salvador, v. 23 n. 58 p. 59-73, 2010.

FLEURY, S. Militarização do social como estratégia de integração: o caso da UPP do Santa Marta. Sociologias, Porto Alegre, v. 14 n. 30, p. 194-222, 2012.

FREEMAN, J. Neoliberal accumulation strategies and the visible hand of police pacification in Rio de Janeiro. Revista de estudos universitários, São Paulo, v. 38, n. 1, p. 95-126, 2012.

GLEDHILL, J. The new war on the poor: the production of insecurity in Latin America. Londres: Zed Books, 2015. $248 \mathrm{p}$.

GLEDHILL, J.; HITA, M. G. ¿Las redes de organización popular aún pueden cambiar la ciudad? El caso de Salvador, Bahía, Brasil. In: DI VIRGILIO, M.; PERELMAN, M. (Ed.). Ciudades latinoamericanas: desigualdad, segregación y tolerancia. Buenos Aires: CLACSO, 2014. p. 85-112.

HARVEY, D. Neoliberalism as creative destruction. The ANNALS of the american academy of political and social science, Nova Iorque, v. 610, n. 1, p. 21-44, 2007.

Rebel cities: from the right to the city to the urban revolution. Londres: Nova Iorque: Verso Books, 2012. 187 p.

HITA, M. G. From resistance avenue to the plaza of decisions: new urban actors in Salvador, Bahia. In: GLEDHILL, J.; SCHELL, P. (Ed.). New approaches to resistance in Brazil and Mexico. Durham: London: Duke University Press, 2012 .p. 269-88.

HITA, M. G.; GLEDHILL, J. Antropologia na análise de situações periféricas urbanas. Cadernos metrópole, São Paulo, v. 12, n. 23, p. 189-209, 2010.

LEITE, R. P. Contra-usos e espaço público: notas sobre a construção social dos lugares na Manguetown. Revista brasileira de Ciências Socias, São Paulo,v. 17, n. 49, p. 115-172, 2002.

MARICATO, E. Metrópole, legislação e desigualdade. Estudos avançados, São Paulo, v. 17, n. 48, p. 151-66, 2003.

“É a questão urbana, estúpido.” In: VAINER, C. B. Cidades rebeldes: passe livre e as manifestações que tomaram as ruas do Brasil. São Paulo: Boitempo, 2013. p. 33-46.

MARQUES, E. Salvem Salvador. Caros Amigos, n. 223, out. 2015.

MONTOYA URIARTE, U. A rebelião do vivido. Henri Lefebvre no centro de Salvador. In: SEMINÁRIO INTERNACIONAL URBICENTROS 3., 2012, Salvador. Anais... Disponível em: <http://www.ppgau.ufba.br/ urbicentros/2012/ST114.pdf>. Acesso em: 6 jan. 2012.

MOURAD, L. N. A verdadeira face do processo de reabilitaçã̃o do Centro Histórico de Salvador. In: ST2: PRODUÇÃO CONTEMPORÂNEA DO ESPAÇO E PROJETOS DE URBANISMO - UrbBA, 11., 2011, Salvador. Anais... Salvador: [S.n.], 2011. Disponível em: <http:// www.ppgau.ufba.br/urba11/ST2_A_VERDADEIRA_FACE_ 
DO PROCESSO DE REABILITACAO DO CENTRO HISTORICO DE $\overline{\mathrm{S}} A L \bar{V} A D O R . p d f>$. Acesso èm: 6 jan. 2015.

MOURAD, L.; FIGUEIREDO, G. C.; BALTRUSIS, N. Gentrificação no Bairro 2 de Julho, em Salvador: modos, formas e conteúdos. Cadernos metrópole, São Paulo, v. 16 , n. 32, p. 437-60, 2014.

NETO entrega títulos de moradia. Correio da Bahia, Salvador, 15 mar. 2015

PLANO guia de arquitetura e paisagem. [20--]. Disponível em: <http://www.cidade-salvador.com/seculo21/planoarquitetura.pdf $>$. Acesso em: 10 jan. 2015.

ROLNIK, R. Remoções forçadas em tempos do novo ciclo econômico. Carta Maior, 2012. Disponível em: <http:// www.cartamaior.com.br/templates/materiaImprimir. cfm?materia id=20790>. Acesso em: 6 jan. 2015.

ROLNIK, R.; KLINK, J. Crescimento economico e desenvolvimento urbano: por que nossas cidades continuam tão precárias? Novos Estudos-CEBRAP, São Paulo, n. 89, p. 89-109, 2011.

SERPA, A. Direito à moradia e funcão social da propriedade: avanços e recuos. In: GLEDHILL, J.; HITA, M. G.; PERELMAN, M. (Ed.). Disputas em torno do espaco urbano processos de produção/construção eapropriação da cidade. Salvador: Edufba, 2017. p. 175-186.
SANTOS, J. L. de J. A cidade poli(multi)nucleada: a reestruturacão do espaço urbano em Salvador. Salvador: Edufba, 2013. 327 p.

SANTOS, M. O centro da cidade do Salvador: estudo de geografia urbana. Salvador: Universidade da Bahia, 1959.

SOUZA, A. G. Limites do habitar: segregação e exclusão na configuração urbana contemporânea de Salvador e perspectivas no final do Século XX. Salvador: Edufba, 2000. 406p.

Favelas, invasões e ocupacões coletivas nas grandes cidades brasileiras: (re)qualificando a questão para Salvador-BA. Cadernos metrópole, São Paulo, n. 5, p. 63-89, 2001

VASCONCELOS, P. de A. Salvador: Transformações e Permanências (1549-1999). 2. ed. amp. Salvador: Edufba, 2016. $569 \mathrm{p}$

WACQUANT, L. Territorial stigmatization in the age of advanced marginality. Thesis eleven, Boondora, v. 91, n. 1, p. 66-77, 2007

Punishing the poor: the neoliberal government of social insecurity. Durham: Londres: Duke University Press, 2009. 408 p. 


\section{URBAN REQUALIFICATION AND EVICTIONS IN SALVADOR'S NEW AND OLD CITY CENTERS}

\author{
John Gledhill \\ Maria Gabriela Hita
}

The city of Salvador replicates the process of "accumulation by spoliation" characteristic of the neoliberal urbanism around the world. In this paper, we compare how the logic of urban requalification operates in two areas of the city. The first area is a large and historically combative favela located in the region that has become the latest "new Centre" of the city. In this region, the key issues are the new urban mobility projects and the construction of housing for other social classes. The second area is the colonial Center of the city, which is undergoing a new gentrification phase. There, the historical heritage policies meet other policies, transforming the remaining public spaces of the securitized neoliberal city into safer areas for tourists and wealthier residents. We emphasize the worth of an ethnographically-based understanding to comprehend the meaning of these changes to poor residents of the city, as well as the complexity, heterogeneity and ambiguity of their different reactions.

Keywords: Cities. Pelourinho. Gentrification. Evictions. Resistances.

\section{REQUALIFICATION URBAINE ET EXPULSIONS DANS DES CENTRES, NOUVEAU ET ANCIEN, DE SALVADOR}

\author{
John Gledhill \\ Maria Gabriela Hita
}

La ville de Salvador reproduit le processus "d'accumulation par spoliation", caractéristique d'un urbanisme néolibéral à travers le monde. Nous faisons, dans cet article, la comparaison du fonctionnement de la logique de requalification urbaine dans deux parties de la ville. La première est une grande favela historiquement combative située dans une région qui est devenue le plus moderne "nouveau centre-ville". En son sein, les nouveaux projets de mobilité urbaine et la construction de copropriétés destinées à d'autres classes sociales sont la clé du problème. La deuxième partie est le centre historique colonial de la ville qui connaît une nouvelle phase de gentrification. Là, les politiques du patrimoine historique se voient confrontées à d'autres politiques qui transforment les espaces publics restants de la ville néolibérale titrisée en zones plus sûres pour les touristes et les résidents plus aisés. Nous insistons sur l'importance d'une compréhension fondée sur l'ethnographie pour saisir ce que ces changements signifient pour les habitants pauvres de la ville ainsi que la complexité, l'hétérogénéité et l'ambiguïté de leurs différentes réactions.

Mots-CLÉs: Villes. Pelourinho. Gentrification. Expulsions. Résistances.

John Gledhill - Professor Emérito da Universidade de Manchester. Editor da revista internacional Critique of Anthropology. Membro da Academia de Ciências Sociais do Reino Unido e da Academia Britânica. Tem realizado pesquisas etnográficas e históricas no México e no Brasil sobre uma variedade de temas e populações indígenas e mestiças, tanto em zonas rurais quanto urbanas, e sobre migração internacional e relações transnacionais. Seus livros monográficos mais recentes são: The New War Against the Poor: the production of insecurity in in Latin America (Zed Books, 2015) e La cara oculta de la inseguridad en México (Paidós, 2017).

Maria Gabriela Hita - Doutora em Antropologia. Professora do Departamento de Sociologia e dos Programas de Pós-Graduação em Ciências Sociais (PPGCS) e o de Estudos Interdisciplinares sobre Mulheres, Gênero e Feminismo (PPGNEIM) da Universidade Federal da Bahia. PQ-2 do CNPq no Núcleo de Estudos em Ciências Sociais, Ambiente e Saúde (ECSAS/PPGCS) da Universidade Federal da Bahia. Fez visitas acadêmicas Pós-doutorais na Universidade de Manchester - Reino Unido (em 2008, 2013 e 2018). Desenvolve pesquisas sobre temas urbanos e pobreza, género, família, parentesco, saúde e raça. Entre seus principais livros publicados estão: A Casa de Mulheres n'outro Terreiro: famílias matriarcais em Salvador (2014); Disputas em torno do Espaço Urbano: processos de [re]produção/construção e apropriação da cidade, co-organizado com Gledhill e Perlman; Raça, racismo e genética em debates científicos e controvérsias sociais (2017) (organizadora). 